\title{
Civilisations
}

Revue internationale d'anthropologie et de sciences

humaines

$51 \mid 2004$

Religions transnationales

\section{Re-Africanization in Secondary Religious Diasporas: Constructing a World Religion}

\section{Alejandro Frigerio}

\section{(2) OpenEdition \\ Journals}

Electronic version

URL: http://journals.openedition.org/civilisations/656

DOI: 10.4000/civilisations.656

ISSN: 2032-0442

\section{Publisher}

Institut de sociologie de l'Université Libre de Bruxelles

\section{Printed version}

Date of publication: 1 January 2004

Number of pages: $39-60$

ISSN: 0009-8140

Electronic reference

Alejandro Frigerio, « Re-Africanization in Secondary Religious Diasporas: Constructing a World

Religion », Civilisations [Online], 51 | 2004, Online since 06 January 2009, connection on 30 April 2019 URL : http://journals.openedition.org/civilisations/656 ; DOI : 10.4000/civilisations.656

This text was automatically generated on 30 April 2019.

(C) Tous droits réservés 


\title{
Re-Africanization in Secondary Religious Diasporas: Constructing a World Religion
}

\author{
Alejandro Frigerio
}

1 The most important recent development in the history of Afro-American religions is their expansion across ethnic and national barriers. No more confined to the cities or areas in which they developed, they have extended over state borders and, increasingly, national ones. Thus, the candomblé of Bahia has moved to Rio de Janeiro and São Paulo (Prandi, 1991, 1998; Silva, 1995; Capone, 1996, 1999a) and from there to Argentina. The batuque of Porto Alegre has spread to Montevideo (Hugarte, 1998) and Buenos Aires (Frigerio, 1998a; Oro, 1999). Uruguayan devotees have taken the Brazilian par excellence (Concone 1987) umbanda to Venezuela (Pollak-Eltz 1993) and Argentine practitioners are taking it to Spain and Italy. Cuban santería, on the other hand, has spread rapidly in the U.S. through Cuban, Puerto Rican and African-American leaders (Brandon, 1997; Gleason, 1975; Gregory, 1986; Palmié, 1995; Capone, 1999b, 1999c). It has also found a place in Venezuela, where it threatened to overcome the native cult of Maria Lionza (Pollak-Eltz, 1985), is flowing into Mexico, and making its way into Europe (Capone, 2001-2002; Capone and Teisenhoffer, 2001-2002; Argyriadis, 2001-2002).

2 Some of the entrepreneurs who pioneered the spread of Afro-American religions through these diverse countries are black, but many or most are white. In cities like São Paulo, Montevideo or Buenos Aires, where they have an important number of followers, the overwhelming majority of the new converts are white. In some cases, like Argentina and Uruguay, Afro-Brazilian religions expanded mostly through the efforts of nationals who were initiated in Brazil. In the U.S., to the contrary, santería was present at first mostly within the Cuban immigrant community, and then spread into other segments of the society, becoming popular with Puerto Ricans and African-Americans, later with other Latino populations and West Indian immigrants, and finally incorporating AngloAmericans into its files. 
3 The diffusion of these religions has created networks of ritual kinship that now span national boundaries giving rise to transnational communities of worshippers. These transnational communities were originally mostly binational, composed by the initiates in the new host societies and their ritual family (or families) in the mother country. Such earlier disparate communities are now being superseded by the development of a wider, more complex one, integrating worshippers in different countries, coming from the practice of different national variants of Afro-American religions. These individuals have an awareness of belonging to a religion that is not circumscribed anymore by national variants but that has given rise to a transnational community of worshippers of the orisha having Yorubaland as its origin, its contemporary model and Mecca.

The paper shall argue that there are stages in the formation of these transnational communities that are related to the religious careers of the practitioners, since the different religious variants they encounter in this path have different implications for their development. The religious communities devotees encounter are first mostly local, then incipiently transnational and finally, for some, transnational global ones.

5 In this process of increasing transnationalization, the nationality of origin of the different Afro-American religious variants remains important and must be dealt with in different ways throughout the individual's religious career. I will argue that the re-Africanization processes that have been observed in practically all Afro-American variants in their new settings (Prandi, 1991; Frigerio, 1993, 2002b; Silva, 1995; Palmié, 1995; Capone, 1999a, 1999b, 1999d) constitute the latest stage in the development of these religions and that they are instrumental in the creation of a world religion and of a truly multifarious transnational community of worshippers.

6 My interpretation intends to be valid for most new settings into which these religions spread -locations that I have elsewhere argued comprise a secondary religious diaspora (Frigerio, 2002c). Although, admittedly, my argument is colored by an intensive fieldwork experience in the Southern Cone of South America (Frigerio, 1989, 1993, 1999, 2002a, $2002 \mathrm{~b}$ ), I believe that there are enough similarities in the process of expansion of most Afro-American religions to warrant such a general rendition (Frigerio, 2002c) ${ }^{1}$. These resemblances may be found in an examination of the growing literature on AfroAmerican religions in secondary diaspora settings -especially in the Southern Cone and in the United States, the areas where the expansion of these religions has become more significant, and the studies about it stronger. Correspondences include the spread, in North and South America, of different yet functionally equivalent religious variants; a comparable sequencing of the religious careers of the individuals and, especially, very similar reactions to this new religious presence in the host societies regardless of the dominant cultural context (Catholic or Protestant). This paper is an attempt to go beyond the local character of most studies on the expansion of Afro-American religions (with the exception of Capone, 1999c, 2000; Oro, 1999 and Frigerio, 2002c) and is based on the belief that our current knowledge of these phenomena allows us to undertake analyses that are more general in scope.

\section{Primary and Secondary religious diasporas}

7 I have argued that it is helpful to distinguish between primary and secondary religious diasporas in order to understand the increasingly complex panorama produced by the 
spatial displacement of Afro-American religions and their adoption by an ever more varied constituency (Frigerio, 2002c) ${ }^{2}$. Although Afro-American religious variants developed in different cities and regions, there are enough similarities in their situation in their locales of origin that warrants that we group them together as a primary religious diaspora. In contrast, the regions and cities towards which they migrated can be considered a secondary religious diaspora. According to this rationale, Bahia, Recife, São Luis de Maranhão, Porto Alegre, Havana or Port au Prince and their surrounding areas, as birthplaces of candomblé, xangô, tambor de mina, batuque, regla de ocha and vodoun respectively-can be considered a primary religious diaspora. The cities, regions and countries to which some of these variants have migrated can be considered a secondary religious diaspora. This secondary diaspora includes cities like Rio de Janeiro, São Paulo, Buenos Aires, Montevideo, New York, Miami, Los Angeles, San Francisco, San Juan de Puerto Rico and Caracas, where Afro-American religious variants are present in important numbers -their temples numbering, at least, in the hundreds ${ }^{3}$.

8 For this paper, the most sociologically relevant aspect of the spatial displacement that warrants this distinction is that in the secondary religious diaspora the social standing these religions had obtained in the primary one has to be regained ${ }^{4}$. In their places of origin, these religions had, after a long struggle, become accepted as part of the legitimate cultural (and sometimes spiritual) heritage. In secondary diaspora settings, new narratives of national belonging need to be created, as accusations that were successfully refuted in the primary diaspora where these religions originated are reiterated or new ones are concocted (Frigerio, 1991a; Birman, 1999).

The main problem that practitioners in secondary religious diaspora locales face regarding legitimation vis-a-vis the host society is that Afro-American religions have, to this day, rarely gained the status of true « religions » (Frigerio, 2002b). Even in primary diaspora settings their legitimation was mostly attained by having been awarded the status of « cultural heritage " of an ethnic or racial group, and, especially, because they were seen as fulfilling the vital function of «cultural resistance $»^{5}$. Their value, as Dantas (1988) has shown for Brazil, and Palmié (1998) and Argyriadis (1999b) for Cuba, has come from their being visualized as the core of the culture of an ethnic group that came to be considered as central to the conformation of national or regional identities ${ }^{6}$. Their legitimation, therefore, is tied to certain local narratives of identity, and is lost when these religions migrate to other areas or countries where these narratives are not meaningful.

10 It is because they have been legitimated as national or regional religions in primary diaspora settings that they find great difficulties in being considered a world religion like Christianity or Buddhism -which would make them naturally available to anyone (regardless of social class, race and nationality) in secondary diaspora settings. Because of their local character, they raise suspicion when practiced by people who do not share this national or regional origin nor belong to the ethnic group that originated them.

11 Not all the Afro-American religious variants face this problem with the same intensity. Some of them bind individuals primarily to religious communities in their own society and do not emphasize their foreign national character. Others, as will be seen, bind devotees to transnational communities of worshippers in ways that may become socially problematic. Thus, sooner or later, the religion's foreign national character must be deemphasized or re-signified. Re-Africanization, I will argue, provides an interpretive frame 
that is particularly suited to transcend nationality constraints and to provide the semblance of a world religion.

\section{Religious careers in secondary diaspora settings}

Reviewing studies on conversion to new religious movements, James Richardson has argued that scholars must move beyond «the assumption that most conversions are single-event types" and that they frequently involve the passage through several religions throughout an individual's lifetime. He has proposed the notion of conversion careers that « is tied to the idea of serial alternatives, by which is meant the sequential trying out of new beliefs and identities in an effort to resolve felt difficulties (...) most contemporary conversions are identity sequences that can often be viewed as cumulative »(Richardson, $1980: 49$ ).

Based on this perspective that emphasizes process, sequentiality and the search for new beliefs and identity transformation as a problem solving strategy, I have argued elsewhere (Frigerio, 2002c) that the analysis of the religious career of devotees of AfroAmerican religions helps to understand more fully the multifaceted, complex character of their transnationalization ${ }^{7}$. This concept underscores the fact that individuals do not make a single option at a certain moment in time for membership into santería, batuque or candomblé, but that they undertake a series of sequential engagements with different variants of Afro-American religions that generally follow a fixed pattern. In their religious career or path, individuals undergo similar or at least comparable changes in their personal and social identities, and get to partake of different collective identities proposed by the religious communities they become members of (Frigerio, forthcoming). This happens in the Southern Cone as devotees traverse from umbanda to batuque to a reafricanized variant of Afro-American religion and, likewise, in the United States, as they proceed from espiritismo to palo to santería, to, perhaps, the "Yoruba religion » or the " orisha religion", as the more re-africanized versions are known. As they progress through these variants, the ritual and theological knowledge of devotees increases, they establish relations with different spiritual beings and they undergo identity changes at personal, social and collective levels ${ }^{8}$. Also, as shall be argued later, in this spiritual path the religious community they are part of becomes larger and wider, as they enter into ritual kinship networks which are, at first, local, and then increasingly transnational.

The idea of religious careers presupposes a processual, diachronic perspective that helps to understand how individuals who do not have these religions as part of their immediate cultural heritage are gradually and sequentially socialized into them. It also shows the logic underlying the consecutive initiations into the different religious variants -a process that shows striking similarities even across national borders. Some variants (like umbanda or espiritismo) are especially suited for introducing individuals into the general religious worldview of these religions (Frigerio, 1990; Carozzi and Frigerio, 1997 ; Frigerio, 1999). They act as cognitive bridges between the folk Catholicism that is practiced by most Latin Americans and the more African variants that have some theological concepts and rituals that are unfamiliar to it (Carozzi and Frigerio, 1992, 1997). These other variants (like batuque or santería) are seen as more powerful and subsequent initiation into them is regarded as mandatory in order to solve health or personal problems. Finally, the re-africanized variants, as shall be argued later, are considered better for 
legitimation purposes vis-a-vis the society and individuals adopt or develop them in the later stages of their religious career.

Three main variables shape the form the religious career takes : the fulfillment of the religious needs of the individual (in terms of magical power and religious knowledge), his requirements of legitimation vis-a-vis other practitioners in his religious community, and the necessity of legitimation vis-a-vis the society in which he practices. The increasing Africanization and re-Africanization processes that several researchers have notedespecially in secondary diaspora settings- can be better understood as distinct strategies employed by individuals to satisfy some of the aforementioned needs at different stages of their religious careers. These two labels -sometime used interchangeably- should be diffe-rentiated in order to more profitably distinguish between different religious phenomena.

Africanization, is better suited to define the passage from the practice of a more syncretic variant like umbanda or espiritismo to a more African one like candomblé, batuque or santería. It occurs rather early in the religious career of the individual, and is a second step that plunges him into what devotees believe is the heart of the religious experience (Prandi, 1991). Re-Africanization is a process undergone by individuals who already practice candomblé, batuque or santería (or other comparable ones like tambor de mina or xangô) who, unsatisfied with the religious knowledge they have received, look to current day Africa, especially Yorubaland, as the true source of theological and ritual knowledge. Through this process Africa comes to be regarded not only as the remote origin of the religious tradition but also as contemporary model for its practice. Current African (mainly Yoruba) religious beliefs and practices move center stage. Re-africanized practitioners (who mostly reside in secondary diaspora settings) take courses in Yoruba language and culture; acquire books on Ifa divination and mythology; wear clothes and exhibit statues and ritual paraphernalia imported from Yorubaland, and sometimes undergo initiations with religious practitioners of this origin (Prandi, 1991; Silva, 1995; Palmié, 1995; Capone, 1999a, 1999d). Re-Africanization generally occurs in the later stages of the religious career, after the individual has moved through umbanda or espiritismo and undergone initiation into one or more nations of candomblé or santería or other more African variants9.

17 These two processes (Africanization and re-Africanization) have generally been considered as one, as the continuous quest for a purer, more African tradition and considered mostly as a legitimating strategy vis-a-vis other religious practitioners (Prandi, 1991; Silva, 1995; Capone, 1999a, 1999d). I have agreed with the gist of this interpretation (Frigerio, 2002c), but here I want to stress that this strategy has not only inward legitimating functions -pertaining to the community of believers- but also outwards, in respect to the host societies in secondary diasporas. Also, I want to argue that Africanization and re-Africanization may be more usefully examined as separable processes that have different consequences at a micro (individual), meso (religious community) and macro (host society) levels of analysis. They have different impacts on the life of the individual, on the bonds established within the religious community, and on the relationship that is established with the host society. 


\section{a. First stage in the religious career : umbanda or espiritismo}

18 Most temples of Afro-American religions in secondary diasporas practice a "more African » variant that involves animal sacrifices (batuque, candomblé, santería) as well as a «more syncretic» one (umbanda, espiritismo) that contains ritual and theological elements that resonate with preexistent religious beliefs and practices ${ }^{10}$. These variants are considered stages in the same religious path. Individuals generally start their religious career in the "more syncretic » variants and are later initiated -by the same religious leader and in the same temple, if no conflict has ensued between them- in the "more African" one. This joint practice serves a twofold purpose. In the case of umbanda, especially, it allows practitioners, if need be, to publicly identify with the " more syncretic ", generally also more socially respectable variant that does not perform animal sacrifices. This is important since the practice of animal sacrifices has become their main stigmatizing feature in all the new societies into which they have expanded (Prandi, 1991; Frigerio, 1991a; Green, 1991; Murphy, 1995; Bartkowski, 1998; Frigerio and Oro, 1998). Second, and most importantly, the «more syncretic» variant serves as a cognitive bridge in the passage from preexistent belief systems (folk Catholicism in the case of Latin America) to Afro-American religions ${ }^{11}$.

This is why, I contend, rarely, if ever, candomblé, batuque or santería exist as the sole Afro-American religious variant present in secondary diaspora settings. In temples in Argentina and Uruguay, batuque is practiced with umbanda (Frigerio, 1989; Carozzi and Frigerio, 1997; Pi Hugarte, 1998) and the same is true for candomblé houses in São Paulo (Prandi, 1991) and Rio (Capone, 1999a) ${ }^{12}$. In Venezuela, santería was mixed with the local cult of Maria Lionza, a kind of local umbanda (Pollak-Eltz, 1985). In Puerto Rico and the United States, santería is very frequently practiced jointly with espiritismo (Schmidt, 1995 ; Gregory, 1986 ; Matory, 2000 : 9-10).

What I argue here, and have shown in detail for the Argentine case (Carozzi and Frigerio, 1997; Frigerio, 1999) is that the "more syncretic » variants function as cognitive bridges between preexistent systems of belief and the more (ritually, theologically) alien world of santería, batuque or candomblé. For Latin American populations, especially, umbanda, the cult of Maria Lionza or espiritismo are very close to the world view of folk Catholicism and prior conversion to these variants allows for later and gradual socialization into the more African and alien worldview of the Afro-American religions. This function of cognitive bridging is especially important in secondary diaspora settings, where people are totally unfamiliar with Afro-American religions ${ }^{13}$.

21 In secondary diaspora settings, not only is the simultaneous practice of two variants noteworthy, but also especially important is the diachronic nature of their relationship. This diachronic nature may be appreciated at a social and at an individual level. In São Paulo, Buenos Aires and Montevideo, for example, umbanda was the first variant that was introduced, and then, after several years of practice, leaders were initiated into candomblé (in the Brazilian metropolis) and batuque (in the other cities) (Prandi, 1991; Frigerio, 1989, 1998; Pi Hugarte, 1998). In these cities, at an individual level, umbanda is considered to be the first step in a religious path that leads to candomble or batuque which are considered the core of the religious system (Frigerio, 1989, 1990, 1999; Prandi, 1991: 78, 87). Devotees begin their religious career in umbanda, and later undergo initiation into candomblé or batuque. 
Even if both variants, a more African and a more syncretic one, migrate together -as happened with santería and espiritismo in the USA-it is probably the case that individuals will encounter or engage in the practice of one variant first, and then the other ${ }^{14}$. Several authors have remarked that, for santería practitioners in the USA and Puerto Rico, espiritismo is considered the first stage in the spiritual path of la religión which leads towards ocha (Capone, 1999b : 50, 1999c : 60; see also Gregory, $1986: 122,130$, 165; Schmidt, 1995 : 102; Perez y Mena, $1998: 22$ ).

\section{b. Second stage in the religious career : Africanization}

Africanization, I propose, occurs when an individual passes from the practice of a more syncretic variant like umbanda or espiritismo to initiation into a more African one like candomblé, batuque or santería. The more African variant is considered to be the core of the religious belief system. At the same time, it is also thought to be magically stronger (Prandi, 1991: 74, 1999 : 158, 162; Frigerio, 1990; Carozzi and Frigerio, 1997; Capone, 1999c: 60). For this reason sooner or later most individuals are initiated into these variants -generally after experiencing some kind of personal crisis, very persistent health problem, etc. It is the use of blood in the rituals that makes the initiation and the works "stronger » than its counterparts in umbanda or espiritismo. The use of this element to create a "seat" (material receptacle) of the individual's personal orisha is believed to create an intense bond between them that cannot be broken. This is the reason why initiation into more African variants of the religion are undertaken only after a certain period of experimentation with introductory or bridging variants like umbanda or espiritismo ${ }^{15}$.

The transition from a more syncretic variant to a more African one can be considered a process of Africanization. It is through this passage that the individual starts participating in religious rituals in which Catholic symbolism is minimized or disappears, songs are sung in "African » languages and not in Portuguese or Spanish, people are possessed by orishas and not spirits of indians, blacks or other deceased individuals. This process, however, should be differentiated from re-Africanization-which many individuals may (or not) undergo later- since its consequences differ at three important levels : individual, meso and macro.

Africanization is a process that is often undergone because of its important consequences at an individual level. It is mostly a quest for stronger magical power that leads to a deeper religious commitment. In this process, the individual establishes a life-long relationship with his orisha(s) who will help and support him in his daily life provided he reciprocates with regular offerings and feasts. He learns new songs, dances and rituals to worship his orishas, as well as the theological concepts that underlie these activities ${ }^{16}$.

At a meso, or group level, Africanization has important consequences since it binds the individual to the religious community that practices the Afro-American variant -which is generally more extended than the one that practiced umbanda or espiritismo. He may continue to attend the weekly umbanda, caboclo or espiritismo ceremonies but now also attends orisha feasts at his temple and, especially, starts visiting the ones that take place in other temples. He now becomes a part of the hierarchical structure of the religious community and has to pay homage to his ritual father or godfather -who may reside in his country or in another one- as well as to his ritual kin (Prandi, 1990) ${ }^{17}$.

In transnationalized African-American religions -or expanding ones- Africanization oftentimes implies regular visits to another city or country. The individual becomes part 
of a ritual kinship system that binds him to a religious community, which often spans regional or national spaces. São Paulo candomblé priests, for example, may have ritual parents or grandparents in Bahia. Argentine batuque practitioners may have them in Porto Alegre (Brazil) or in Montevideo (Uruguay). North Americans may be linked through their padrino or madrina to leaders in Havana or Matanzas, or may themselves have been initiated there. In all these cases, they belong to a religious community that spans regional or national borders. Another city of the Americas becomes their religious Mecca -Bahia, Porto Alegre, Havana. They may have to visit it on at least a yearly basis for their subsequent ritual initiations or to attend their ritual parent or grandparent's festivities (Oro, 1999).

28 Through this process the individual becomes part of an incipient transnational community. It is transnational because it spans national borders, and creates a sense that the individual's religious activities have a here, in the country where he lives, and a there, the country in which his religious «father» (or « godfather») or even " grandfather» lives ${ }^{18}$. I consider it incipient because at this stage this community is mostly binational (Argentine-Brazilian; Cuban-North American). Since candomblé or batuque and santería have explicit and recognized national origins, the recent initiate establishes a strong link only with the nation (or city) of origin of the religion he practices ${ }^{19}$. Also, the link is mostly with the extended ritual kinship family to which he belongs and much more tenuous with the rest of the community. Compared to later, wider and more diversified relationships that more seasoned veterans establish-discussed below- this transnational community can be considered an elementary one.

29 At a societal or macro level Africanization processes in secondary diaspora settings generally do not help in the legitimation of the religion. They increase and make more widespread the use of animal sacrifices, and generally diminish the amount of individuals who practice less controversial variants like umbanda or espiritismo. Since more African variants have been legitimized in the primary diaspora for cultural and ethnic reasons, not for religious ones, the practice of a racialized religion by white individuals in novel societies of the secondary diaspora increases the problematization of the religious community. It also furthers, as we saw, the identification of the religion with a foreign nationality (Brazilian or Cuban mostly) and generally does not provide an interpretive frame with a narrative of national belonging that connects the religious community or the religion with the host society (Frigerio, 2002b). Practitioners in secondary diaspora settings who are undergoing or have recently undergone Africanization are still too tied to the interpretive frame of their foreign mentors. This frame developed in another country (Brazil or Cuba) and explains the religion's origin, its social place and worth in terms of the cultural dynamics of the society of origin. It is totally inadequate to explain its significance in another country ${ }^{20}$.

As individuals who have undergone Africanization mature in their religious careers, however, they start developing interpretive frames of their own, which allow them to gain independence from their previous foreign mentors as well as to legitimate the religion in their own country. This interpretive frame provides a local narrative of national belonging justifying why the religion is present in the country and why devotees are entitled to its practice. In Latin American countries, and most notably in the Southern Cone, the first step is to de-nationalize the religious variant, emphasizing that, as African religions, they were found in the past in any place in the Americas where a Black population existed. These religions, it is argued, are not the sole patrimony of the 
countries where the present day variants originated, but constitute a common heritage of Latin American countries -no matter how much a country's dominant national narrative downplays this heritage, as is the case in Argentina, for example (Frigerio, 2002b).

31 Likewise, I argue that behind the "Africanizing» and «Cubanizing» discourses that Palmié (1995) noted divide African-American and Cuban practitioners in the USA lie not only different ideas about the role of «syncretism " within similarly divergent notions of «tradition» (as he cogently showed) but also an attempt by the former to de-Cubanize santería. "Africanizing » discourses not only provide a way in which African Americans can gain a measure of autonomy from their Cuban mentors but also a way in which the religion may lose its connotation as a migrant Cuban religion and become a part of the African-(North) American heritage.

Brandon notices how, similarly, Puerto Rican practitioners appropriate the Cuban orishas :

«The eruption of blackness in the form of the Seven African Powers present in santerismo, therefore represents an affirmation of Africa as an aspect of Puerto Rican ethnic identity. Once the Seven African Powers become encapsulated and redefined with the context of santerismo's ideology and embedded in its symbolism, they cease to be Cuban. They have been appropriated ideologically, and in terms of ethnicity they have become Puerto Rican " (Brandon, 1997 : 113).

I have shown that similar strategies are employed by Argentines who, in order to deemphasize the foreign character of their religions -in a social context that stigmatizes alien sects- stress the African roots and heritage of their country. By finding African culture and religion in Argentina's past, they feel entitled to its practice in the present. This serves both as a rhetoric strategy to gain independence from their Brazilian mentors as much as to show society that they are practicing a religion that has its own roots in the country (Frigerio, 1991b, 1998b, 2002a, 2002b).

34 The growth of these discourses is very frequently accompanied by processes of reAfricanization which, I suggest, represent the ultimate development of this new interpretive frame.

\section{c. Third stage in the religious career : Re-Africanization}

Some years after they have a temple and disciples of their own and are well established in their religious career, it is common for practitioners to seek independence of their mentors. No more passively learning what their teachers would pass on to them, they start to actively influence the way the tradition is transmitted. In secondary religious diaspora settings, this way of intervention seems to be primarily through reAfricanization processes. When several individuals in secondary diasporas are at a similar stage, this translates, at a macro level, into a will to form a local, more autonomous religious movement, independent from the tutelage of primary diaspora mentors.

Several studies have shown remarkably similar processes happening in secondary diaspora settings (Prandi, 1991 ; Frigerio, 1993, 2002b; Silva, 1995; Capone, 1999a, Oro, 1999). In Rio de Janeiro, São Paulo, Buenos Aires, New York and other cities in the US, certain religious leaders not only break away from their original mentors in Bahia, Porto Alegre and Cuba -respectively- but do so in similar manner. They turn to Africa, now viewed not only as the origin of their religion, but as a contemporary source of knowledge with which to improve or deepen the religious understanding that their mentors have 
bequeathed them. The diasporic tradition of the variant they had practiced to that moment is considered, after several years of practice, incomplete and inadequate due to the successive loss of knowledge that, they claim, occurred in its oral transmission.

In this return to Africa, leaders in Rio, São Paulo and Buenos Aires are generally aided by Nigerian immigrants studying at major universities in these cities (Prandi, 1991; Silva, 1995; Capone, 1999a; Oro, 1999). These students often start by teaching classes of Yoruba language and culture -at the university, private institutes or temples- and then move on to lecture on Yoruba rituals and, especially, Ifa mythology. Most of them are not originally devotees of African religions, and so must rely heavily on the published works of Abimbola $(1976,1977)$ or Bascom $(1969,1980)$ to teach their classes. Some of them later undergo initiation into the Yoruba religion in Africa -or then claim to have been initiates all along- and eventually even initiate some of their Brazilian or Argentine disciples (Silva, 1995, Capone, 1999a). Other secondary diaspora leaders -especially in the USAhave direct access to the English language literature on African religions and culture. It is also easier for them to directly visit Africa, from where they may return with honorary titles bestowed on them by (better or lesser known) kings or priests from Nigeria (mostly) or Benin. For these secondary diaspora leaders, the gravitational center of their religion has moved to Africa and specifically Yorubaland (Prandi, 1991; Silva, 1995; Capone, 1999a). For most, the new Mecca is now Ilé-Ifé, the place where Oduduwa created the world.

This effort of local leaders to learn the Yoruba language, Ifa mythology, and adopt Yoruba teachers as their main exemplars has been called «Africanization» by Prandi (1991, 1998), and « re-Africanization » by Silva (1995) and Capone (1999a) -a term that I consider more adequate. Although it appears that only a minority of religious leaders undergo reAfricanization, they are probably the most socially visible and outspoken. Usually among the oldest and more formally educated of their peers in secondary diasporas, they most outspokenly and cogently provide new narratives of national belonging for these religions. They propose an interpretive frame providing a model of what the religion should be, and what is its proper place in the society in which they reside. Taking anthropologists, historians, artists, members of African diplomatic corps and government officials as their allies, they out-spokenly encounter social prejudices against their religions and argue for their religious rights. In their efforts to provide a narrative of national belonging, they organize conferences, court the favor of anthropologists (Silva, 1999) -or sometimes oppose them- and take the lead in the interaction with different social institutions of the host society. This interpretive frame, even if it not massively accepted by their peers, generally sets the trend within which -or against which- most practitioners must develop their practice and their conception of their religion. Leaders who have not undergone re-Africanization, may comprise the larger group of practitioners in the country, but are still significantly tied to the narratives of national belonging of their Brazilian or Cuban mentors -narratives that are not well suited for the justification of the presence of Afro-American religions in secondary diasporas. They are generally less worried about social legitimation and generally develop local strategies of adaptation that merely allow them to practice their religion in a precarious equilibrium with the neighborhood police or other municipal institutions. Sooner or later, leaders who wish to engage in collective action and build a collective religious identity -in order to mobilize the religious community to struggle for its rights- must, to a greater or lesser extent, incorporate the re-Africanized narratives (Frigerio, forthcoming). 

and Silva (1995 : 244-287) in São Paulo, and Frigerio (1993, 2002b) and Oro (1999) in Argentina. In the United States, the birth of an African-American variant, called orishavoodoo by practitioners and researchers has been well documented (see especially Brandon, 1997 : 114-120; Palmié, 1995 : 77-80 ; Capone, 1999b : 62-65; Pinn, 2000 ; Hucks, 2000). I will not review these developments again here. More than the specific details of the institutes and individuals involved, what is of interest are the general trends and common elements that can be discerned in all or most of these situations.

Re-Africanization, as several authors have suggested (Prandi, 1991, Frigerio, 1993, 2002 ; Palmié, 1995 ; Capone, 1999a, 2000), is always a process of independence from previous religious mentors, especially from those of primary religious diaspora settings. However, it is also, and especially for the analytical purposes of this paper, a process of constitution of a world religion. Postulating a religion that has one origin, and one way to practice it, freeing it of the local narratives that hinder specific Afro-American religious variants, abolishing -in discourse- the particularities developed in Bahia or Porto Alegre, it vindicates its status as a world religion.

41 In this interpretive frame not only is the local religious community taken into account, but, especially, the transnational one, which has gained increasing relevance during the last two decades. This is a global, more than a national, narrative for the religion. In it, these religions lose their local characters and a conscious attempt is made to transform the different national variants into a world religion, the "religion of the orishas", available to anyone regardless of nationality or race.

\section{Constructing a world religion}

Several authors have called attention to the fact that secondary diaspora practitioners generally have a higher level of education than their mentors and colleagues in primary diaspora settings (Frigerio and Carozzi, 1993 ; Silva, 1995 : 261 ; Epega, 1999 : 162 ; Capone, 1999a: 276; Murphy, 1995 : 294). Leaders who undergo re-Africanization are usually among the most educated in the religious community. They are used to reading books, taking courses, listening to lectures, participating in conferences -or are even lecturers or authors of books themselves. Books written by anthropologists on Afro-American religious variants were always a valuable source of information for devotees (Bastide, 1983 : 168; Silva, 1995 : 250-261), but their use was often hidden or downplayed. Nowadays several priests have no problem in publicly discussing their readings, or even in recommending doctoral dissertations to colleagues and disciples ${ }^{21}$. Furthermore, the books that now circulate among this elite do not focus, as they used to, on a primary diaspora variant (candomblé or santería) but on Yoruba language and mythology. Many are written by Nigerian professors lecturing in Brazil, or are translations of the classic works on Ifa in Africa (and Cuba) written by Bascom $(1969,1980)$ or Abimbola $(1976$, 1977).

Given this more modern and formally educated constituency, re-Africanization as Prandi (1998 : 162-163) suggests, involves an increasing intellectualization of the religion, as well as an encouragement for bricolage. Re-Africanization implies a higher degree of bricolage than before because each temple leader makes his own synthesis of the material he has read or the courses he has attended. Ritual initiation under African tutelage -in secondary diaspora cities or in Africa- is not very frequent, so re-Africanized leaders 
have only a tenuous link with their new mentors. Thus, they are able to synthesize the new knowledge they acquire as they deem best.

Comparing re-Africanization processes with Africanization ones on the dimensions that were discussed above, a number of important differences may be found. At an individual level, re-Africanization does not seem to spring mostly from a desire to overcome personal crises, as was the case in Africanization. For most individuals, it does not involve new initiations, but taking courses, attending lectures, reading books and then performing a bricolage with what they have learned. More than magical power, the individual seems to be in search of an improved conceptual apparatus with which to interpret the world.

At a meso level, if Africanization increased dependence on the leader who initiated the individual into a certain Afro-American religious variant, re-Africanization is a movement of independence. The relationship the individual establishes with his new African mentors is mostly a pay-for-service one, in which money is exchanged for courses or lectures, not for ritual initiations that lead to prolonged dependence. Re-africanized leaders are not linked by a complicated web of spiritual kinship, at least not to the degree that was the case when they africanized and entered candomblé (see Prandi, 1990), batuque or a new nation within them ${ }^{22}$.

If re-Africanization diminishes the bond that the individual had established with the binational religious community to which he was related by ritual kinship established by his religious mentor/s, at the same time it creates an increased awareness of belonging to a global transnational community of orisha worshippers. This consciousness is made possible through encounters in international conferences dedicated to the orisha tradition and culture, and, in these last years, increasingly through the Internet (Capone, 1999b).

47 At a more macro level, re-Africanization in secondary diaspora settings aids in the legitimation of the religious community. It provides an interpretive frame that assertively emphasizes the global character of the religion. This frame postulates a religion that has one origin, one model to follow, and is unencumbered by the several local national narratives that hindered Afro-American religious variants. Abolishing in its discourse the religious and historical particularities that developed in Bahia or Porto Alegre, it vindicates the status of the religion as a world one. Thus, this is no longer an Afro-Brazilian religion mostly for Brazilian devotees, or an Afro-Cuban one mostly for Cubans, but an African one that can be vindicated by any individual who claims to participate, to some degree, of the African genetic, or, especially, cultural heritage. This makes it the rightful prerogative of almost everybody in the American continent, even if, as is the case in Argentina, a counterdominant national narrative that stresses the Black contribution to the nation's culture must be presented (Frigerio, 2002b) ${ }^{23}$.

This interpretive frame, however, strives to make this religion rightfully available to anyone, even beyond the American continent. The mythical origin of humanity that it establishes at Ilé-Ifé, Nigeria, becomes blurred with its scientifically validated one in Africa. A religion coming from the cradle of humanity is thus considered a religion open to anyone regardless of race or nationality. Re-africanized versions of the religion have not only one origin and one Mecca, but also, finally, one book. The strong emphasis reafricanized priests give to Ifa (Capone, 1999b : 63) allows this corpus of mythology to function as a sacred book providing yet another cherished element that upholds claims to the desired new status of world religion. 

educated, powerful Nigerian elite, with strong academic ties and background, as well as political clout. In the 1980s, this group of Nigerian religious entrepreneurs -coming mostly from the city of Ilé-Ifé- made a strong appearance in the diaspora religious communities (Abimbola, 1979) ${ }^{24}$. They were instrumental in the organization of the World Conferences on the Orisha Tradition, and subsequently visited almost all the major cities in the Americas that featured a community of orisha worshippers, becoming the main proponents of a re-Africanization interpretive frame. This discourse was most appealing to the religious leaders of secondary diaspora temples, who saw it as especially adequate for establishing a religious movement that could gain independence from their primary diaspora mentors.

Nigerian embassies in many -probably all- diaspora cities backed the local efforts to teach Yoruba language and culture, as well as the visits of the religious entrepreneurs from IléIfé. These Nigerian entrepreneurs have shown an especially open attitude towards practitioners of re-africanized Afro-American religions regardless of their nationality or race ${ }^{25}$. Primary diaspora leaders, on the other hand, continue tied to Cuban or Brazilian narratives of regional, national and ethnic belonging, and even if they also proclaim the universality of their religion, are always very suspicious of practitioners of different nationality or regional origin. They often view their ex-disciples or would-be peers in secondary diaspora settings with contempt and almost invariably, in the oblique way of Afro-American religious etiquette, find ways to show them their inferior status and knowledge ${ }^{26}$. Nigerian religious entrepreneurs, on the contrary, seem to have fewer qualms in stamping their seal of African purity in any temple or practitioner that pays enough respect -in whatever kind of species is needed ${ }^{27}$.

\section{Conclusions}

51 I have argued that it is helpful to distinguish between primary and secondary religious diasporas in order to understand the increasingly complex panorama produced by the spatial displacement of Afro-American religions and their adoption by a nationally and racially varied constituency. The most sociologically relevant aspect of the spatial displacement that warrants this distinction is that in secondary religious diaspora settings the social legitimation these religions had obtained in the primary diaspora has to be regained. In their places of origin these beliefs and practices were legitimated not by reason of their religious worth but mostly because they fulfilled the function of "cultural resistance» of a racial group that came to be considered important in the conformation of regional or national identities. Tied to local narratives of identity, legitimation is lost when they migrate to other countries where these are not meaningful. Further, having been legitimated as national or regional religions in primary diaspora settings they find great difficulties in being considered a world religion like Christianity or Buddhism -which would make them naturally available to anyone (regardless of social class, race and nationality) in secondary diaspora settings. Because of their local character, they raise suspicion when practiced by people who do not share their national or regional origin nor belong to the ethnic group that originated them. There is a certain variation in the legitimation problems that the migrating religious variants face. Some, like umbanda or espiritismo, are less controversial because they do not advocate the practice of animal sacrifice. Others, like santería or batuque, that perform animal

Civilisations, 51 | 2004 
sacrifices and also entail the creation of transnational communities, suffer a larger amount of problematization.

A processual, diachronic analysis of the religious careers of practitioners of Afro-American religions helps to understand the underlying logic in the passage through the different variants -a progress that shows striking similarities across national borders. Individuals first practice variants like espiritismo or umbanda that act as cognitive bridges between the folk Catholicism that is practiced by most Latin Americans and the more African variants that are unfamiliar to them. Later on, they are initiated into more African ones, like batuque, candomblé or santería, which are thought to be magically stronger and imply a greater degree of commitment with the religion.

Throughout their religious careers individuals also gradually become part of larger transnational communities. The first religious communities devotees encounter are mostly local, then they become part of incipiently transnational ones, and finally some of them feel integrated to transnational global ones.

The nationality of origin of the different Afro-American religious variants remains a significant issue with their transnationalization and is dealt with in different manner throughout the individual's religious career. At a certain stage in their religious development, religious leaders in secondary diaspora settings develop interpretive frames of their own, which allow them to gain independence from their previous foreign mentors as well as to legitimate the religion in their own country. These interpretive frames provide a local narrative of national belonging justifying why the religion is present in the country and why devotees are entitled to its practice. Religious variants are de-nationalized and it is frequently emphasized that, as African religions, they were found in the past in any place in the Americas where a Black population existed. These religions, it is argued, are not the sole patrimony of the countries where the present-day variants originated, but constitute a common heritage of Latin American countries.

Re-Africanization, the ultimate development of this new interpretive frame, is a process of constitution of a world religion in pursuit of the social legitimation these religions lack. Postulating a religion that has one origin, and one way to practice it, freeing it from the local narratives that hinder specific Afro-American religious variants, it vindicates its status as a world religion ${ }^{28}$. It provides a global narrative for the religion, transforming the various local variants into the "religion of the orishas», available to anyone regardless of nationality or race, creating the discursive conditions for the creation of a global transnational community of orisha worshippers.

\section{BIBLIOGRAPHY}

ABIMBOLA, Wande

1976, Ifa. An Exposition of Ifa Literary Corpus, Ibadan and London : Oxford University Press.

1977, Ifa Divination Poetry, New York : Nok Publishers. 
1979, « Yoruba Religion in Brazil : Problems and Prospects », XLII International Congress of Americanists, Paris, vol. 6, pp. 619-639.

ARGYRIADIS, Kali

1999a, La religión à La Havane. Actualité des représentations et des pratiques cultuelles havanaises, Paris : EAC.

1999b, « Une religion vivante. Continuité et complémentarité des pratiques cultuelles havanaises ", L'Homme, 151, pp. 21-46.

2000, « Des Noirs sorciers aux babalaos : analyse du paradoxe du rapport à l'Afrique à La Havane », Cahiers d'études africaines, vol. XL, 160(4), pp. 649-674.

2001-2002, « Les Parisiens et la santería. De l'attraction esthétique à l'implication religieuse », Psychopathologie africaine, vol. XXXI, 1, pp. 17-44.

BARTKOWSKI, John, 1998, «Claims-making and Typifications of Voodoo as a Deviant Religion : Hex, Lies and Videotape ", Journal for the Scientific Study of Religion, 37(4), pp. 559-579.

BASCOM, William

1969, Ifa Divination. Communication Between Gods and Men in West Africa, Bloomington : Indiana University Press.

1980, Sixteen Cowries. Yoruba Divination from Africa to the New World, Bloomington : Indiana University Press.

BASTIDE, Roger

1978, The African Religions of Brazil, Baltimore : Johns Hopkins University Press.

1983, « Contribuição ao estudo do sincretismo católico-fetichista », inEstudos Afro-Brasileiros, São Paulo : Perspectiva.

BIRMAN, Patricia, 1999, « Entre França e Brasil : viagens antropológicas num campo (religioso) minado », Horizontes Antropológicos, 10, pp. 35-60.

BRANDON, George, 1997, Santería from Africa to the New World. The Dead Sell Memories, Bloomington and Indianapolis : Indiana University Press.

CANIZARES, Raul, 1999, Cuban Santería. Walking with the Night, Rochester, Vermont : Destiny Books ( $2^{\text {nd }}$ edition).

CAPONE, Stefania

1996, « Le pur et le dégénéré : le candomblé de Rio de Janeiro ou les oppositions revisitées », Journal de la société des américanistes, 82, pp. 259-292.

1999a, La quête de l'Afrique dans le candomblé. Pouvoir et tradition au Brésil, Paris : Karthala.

1999b, « Les dieux sur le Net : l'essor des religions d'origine africaine aux Etats-Unis », L'Homme, 151, pp. 47-74.

1999c, « Uma religião para o futuro : a rede transnacional dos cultos afro-americanos », Estudos Afro-Asiáticos, 36, pp. 57-72.

1999d, «L'Afrique réinventée ou la construction de la tradition dans les cultes afro-brésiliens », Archives européennes de sociologie, XL (1), pp. 3-27. 
2000, « D'une identité religieuse à une identité 'ethnique' : la communauté transnationale des pratiquants de la religion des orisha», paper presented at the VIII Congreso Latinoamericano de Religión y Etnicidad, Padova, Italia. June 30-July 5.

2001-2002, « La diffusion des religions afro-américaines en Europe », Psychopathologie africaine, vol. XXXI, 1, pp. 3-16.

2003, « Regards contemporaines sur les premiers candomblés à Salvador de Bahia », in Abel Kouvouama et Dominique Cochart (éds.), Modernités transversales : citoyenneté, politique et religion, Paris : Editions Paari, pp. 49-74.

CAPONE, Stefania and TEISENHOFFER, Viola, 2001-2002, « Devenir médium à Paris : apprentissage et adaptation rituels dans l'implantation d'un terreiro de candomblé en France ", Psychopathologie africaine, vol. XXXI, 1, pp. 127-156.

CAROZZI, María Julia and FRIGERIo, Alejandro

1992, « Mamãe Oxum y la Madre Maria : Santos, Curanderos y Religiones Afro-Brasileñas en Buenos Aires », Afro-Asia, 15, pp. 71-85.

1997, « Não se nasce batuqueiro : A conversão às religiões afro-brasileiras em Buenos Aires », Religião e Sociedade, 30, pp. 71-94.

CONCONE, Maria Helena, 1987, Umbanda, uma religião brasileira, São Paulo : USP/CER.

CORRÊA, Norton, 1992, O Batuque do Rio Grande do Sul, Porto Alegre : EDUFRGS.

COSENTINO, Donald, 1993, « Vodou Vatican : A prolegomenon for understanding religious authority in a syncretic religion », Caribbean Quarterly, 39, pp. 100-107.

COSSARD-BINON, Gisèle, 1981, « A filha de santo », in Carlos M. De Moura (éd.), Oloorisa. Escritos sobre a religião dos orixá, São Paulo : Agora.

DANTAS, Beatriz Góis, 1988, Vovó Nagô e papai branco. Usos e abusos da Africa no Brasil, Rio de Janeiro : Graal.

EPEGA, Sandra Medeiros, 1999, « A volta à Africa : Na contramão do orixá », in Carlos Caroso y

Jeferson Bacelar (éds.), Faces da Tradição Afro-Brasileira, Rio de Janeiro : Pallas, pp. 159-170.

FRIGERIO, Alejandro

1989, With the Banner of Oxalá. Social Construction and Maintenance of Reality in Afro-Brazilian Religions in Argentina, Ph. D. dissertation, Anthropology Dept. University of California, Los Angeles.

1990, « Umbanda e Africanismo em Buenos Aires : duas etapas de um mesmo caminho religioso », Comunicações do ISER, 35, pp. 52-63.

1991a, « Nuevos Movimientos Religiosos y Medios de Comunicación : La Imagen de la Umbanda en Argentina », Sociedad y Religión, 8, pp. 69-84.

1991b, « 'La Umbanda no es una Religión de Ignorantes y Mediocres' : La Estigmatización de las Religiones Afro-Brasileñas en Buenos Aires », Revista de Antropología, 10, pp. 22-33.

1993, « De la Umbanda al Africanismo : Identificación Etnica y Nacional en las Religiones Afrobrasileñas en Argentina », in C. Fonseca (éd.), Fronteiras da Cultura, Porto Alegre : EDUFRGS, pp. 92-121.

1998a, «El rol de la 'escuela uruguaya' en la expansión de las religiones afrobrasileñas en Argentina », in R. P. Hugarte (éd.), Los Cultos de posesión en Uruguay. Antropología e Historia, Montevideo : Banda Oriental, pp.75-98. 
1998b, « Les 'sectes' vues par les 'religions' : Le discours médiatique des prêtres et des pasteurs en Argentine », Social Compass, 45(3), pp. 437-459.

1999, «Estableciendo puentes : Articulación de significados y acomodación social en movimientos religiosos en el Cono Sur », Alteridades, 18, pp. 5-18.

2002a, « La expansión de religiones afro-brasileñas en Argentina : Representaciones conflictivas de cultura, raza y nación en un contexto de integración regional », Archives de Sciences Sociales des Religions, 117, pp. 129-151.

2002b, « Outside the Nation, Outside the Diaspora : Accommodating Race and Religion in Argentina », Sociology of Religion, 63(3), pp. 291-315.

2002c, « Africanization, Re-Africanization and Anti-Syncretism in the Primary and Secondary African Religious Diaspora ", Paper presented at the Symposium Africas of the Americas, David Driskell Center for the Study of the African Diaspora, University of Maryland. College Park, Maryland, April 18-20.

Forthcoming « 'Por nuestros derechos, ahora o nunca'! Construyendo una identidad colectiva umbandista en Argentina », Civitas, Revista da Pontificia Universidade Católica, Rio Grande do Sul.

FRIGERIO, Alejandro and ORO, Ari, 1998, « 'Sectas satánicas' en el Mercosur : Un estudio de la construcción de la desviación religiosa en los medios de comunicación de Argentina y Brasil », Horizontes Antropológicos, 8, pp. 114-150.

FRIGERIO, Alejandro and CAROZZI, María Julia, 1993, « As religiões afro-brasileiras na Argentina », Cader-nos de Antropología, 10, pp. 39-68.

GLAZIER, Stephen, 1996, « New World African Ritual : Genuine and Spurious ", Journal for the Scientific Study of Religion, 35(4), pp. 420-431.

GLEASON, Judith, 1975, Santería, Bronx, New York : Atheneum.

GREEN, Thomas, 1991, « Accusations of Satanism and Racial Tensions in the Matamoros Cult Murders ", in J. Richardson, J. Best and D. Bromley (éds.), The Satanism Scare, New York : Aldine, pp. 237-248.

GREGORY, Steven, 1986, Santería in New York City. A Study in Cultural Resistance, Ph. D. dissertation, Graduate Faculty of Political and Social Science, New School for Social Research.

HUCKS, Tracy, 2000, « African American Yorubas in Harlem and the Transition to Oyotunji Village ", in Larry Murphy (éd.), Down by the Riverside. Readings in African American Religion, New York : New York University Press, pp. 256-259.

MATORY, J. Lorand

1999, « The English Professors of Brazil : On the Diasporic Roots of the Yoruba Nation », Comparative Studies in Society and History, 41(1), pp. 72-103.

2000, «The New Yoruba Imperium : Texts, Migration and the Rise of the Trans-Atlantic Lucumi Nation », paper presented at the XXII International Congress of the Latin American Studies Association, Miami, Florida, March 16-18.

MOTTA, Roberto

1988, « A eclesificação dos cultos afro-brasileiros », Comunicações do ISER, 30, pp. 31-43.

1994, «L'invention de l'Afrique dans le candomblé du Brésil », Storia, Antropología e Scienze del Linguaggio, 9(2/3), pp. 65-85. 
1998, « The churchifying of candomblé : Priests, anthropologists, and the canonization of the African religious memory in Brazil ", in Peter Clarke (éd.), New Trends and Developments in African Religions, Westport, CT : Greenwood Press, pp. 45-57.

MURPHY, Joseph, 1995, « Santería and Vodou in the United States », in T. Miller (éd.), America's Alternative Religions, New York : SUNY Press, pp. 291-296.

oRo, Ari Pedro

1999, Axé Mercosul. As religiões afro-brasileiras nos países do Prata, Petrópolis : Vozes.

(éd.)1994, As religiões afro-brasileiras do Rio Grande do Sul, Porto Alegre : EDUFRGS.

PALMIÉ, Stephan

1995, « Against Syncretism : 'Africanizing' and 'Cubanizing' Discourses in North American Orìsà Worship », in R. Fardon (éd.), Counterworks : Managing the Diversity of Knowledge, London :

Routledge, pp. 73-104.

1998, « Fernando Ortiz and the cooking of history », Ibero-Amerikanisches Archiv, 24(3/4),

pp. 353-373.

2001, « Of pharisees and snark-hunters : Afro-Cuban religion as an object of knowledge », Culture and Religion, 2(1), pp. 3-20.

PEREZ Y MENA, Andres, 1998, «Cuban Santería, Haitian Vodun, Puerto Rican Spiritualism : a Multiculturalist Inquiry into Syncretism », Journal for the Scientific Study of Religion, 37 (1) , pp.

15-27.

PI HUGARTE, Renzo, 1998, Los cultos de posesión en Uruguay. Antropología e Historia, Montevideo : Ediciones de la Banda Oriental.

PINN, Anthony, 2000, « Orisha Worship in the United States », in Larry Murphy (éd.), Down by the Riverside. Readings in African American Religion, New York : New York University Press, pp. 243-255. POLLAK-ELTZ, Angelina

1985, Maria Lionza. y culto venezolano, Caracas : Universidad Católica Andres Bello.

1993, Umbanda en Venezuela, Caracas : Acta Científica Venezolana.

PRANDI, Reginaldo

1990, « Linhagem e legitimidade no candomblé paulista », Revista Brasileira de Ciências Sociais, 14, pp. 18-31.

1991, Os Candomblés de São Paulo, São Paulo : HUCYTEC-EDUSP.

1998, « Referências sociais das religiões afro-brasileiras : sincretismo, branqueamento, africanização », Horizontes Antropológicos, 8, pp. 151-167.

SCHMIDT, Bettina, 1995, « Towards a New Merging : Spiritism and the Afro-Puerto Rican Religious Culture », Horizontes Antropológicos, 3, pp. 98-104.

SILva, Vagner Gonçalves da

1995, Orixás da metrópole, Petrópolis : Vozes.

1999, « Reafricanização e sincretismo : Interpretações acadêmicas e experiências religiosas ", in Carlos Caroso y Jeferson Bacelar (éds.), Faces da Tradição Afro-Brasileira, Rio de Janeiro : Pallas, pp. 149-158. 


\section{NOTES}

1. Apart from my own fieldwork on the transnationalization of these religions in the Southern Cone (complemented by the works of Oro, 1999 and Pi Hugarte, 1998), I also draw on some field experience in Los Angeles, where I lived and pursued graduate studies, as well as on my participation in privileged sites of study of the forging of a transnational community : the World Conferences on the Orisha Tradition and Culture. These conferences were the first events that brought together practitioners from many countries in the Americas, and were instrumental in creating an awareness of the existence of a transnational community of worshippers. I took part in three of these meetings : in Salvador, Bahia (1983), New York (1986) and São Paulo (1990).

2. I thank Stephan Palmié for his suggestion to use these terms to distinguish between both types of diaspora -when I was thinking of other, more complicated, ones.

3. I have not added cities in Europe to the list because the number of temples present seems to be small (Capone and Teisenhoffer, 2001-2002; Argyriadis, 2001-2002).

4. In a previous work, I argued that there are three important legitimation problems that practitioners of Afro-American religious variants face in secondary diaspora settings. First, they have to be accepted by the new host society. Second, they must, at a certain stage in the development of their religion, gain a measure of independence from their religious mentors in the primary diaspora. Third, they have to establish a hierarchical structure in the new religious community that is being formed. In brief, they need to be legitimized vis-à-vis the new host society; the religious practitioners in the primary diaspora and their peers in the secondary diaspora setting. I will not, in this article, deal with the last two legitimation problems (they are treated in Frigerio, 2002c).

5. Anthropologists were instrumental in their obtaining this kind of legitimation -having always insisted that these religions performed this academically cherished role (Dantas, 1988; Motta, 1994, 1998; Capone, 1999a).

6. This is no mean feat, since for many years they were considered alien to the societies in which they developed.

7. I prefer to use the term "religious career" rather than "conversion careers " because, differently from the cases studied by Richardson and other scholars of new religious movements, the incorporation of new beliefs and the identity transformations occur through subsequent initiations into different variants of Afro-American religions, that are considered to be within the same religious path, "la religión » (as devotees in Cuba and in the Southern Cone call it).

8. See the religious trajectories described by Carozzi and Frigerio (1997) and Argyriadis (1999a), as well as Frigerio (forthcoming) on the need to distinguish between these different levels of identity.

9. Re-Africanization, I have argued, is more frequent in secondary diaspora settings (Frigerio, 2002c). Practitioners in primary religious diasporas more commonly adopt «churchifying» or «orthodoxization» and «de-synchretization » strategies (Capone, 1999a, 1999b, 1999c, 1999d ; Motta, 1988, 1994, 1998; Cosentino, 1993 and Palmié, 1995). They eliminate or downplay syncretism and take as a model of religious practice and belief not contemporary Africa but the most prestigious temples of the African diaspora in the Americas. Thus, for practitioners in Havana, Salvador or Porto Alegre the « pure » roots of the religious tradition are to be found not in present-day Africa, but in the Afro-American past (Capone, 1999a, 1999c; Palmié, 1995 ; Oro, 1999 ; Frigerio, 2002c).

10. Espiritismo is not strictly an Afro-American religion, but -especially in Cuba and in the USAis frequently practiced in a joint and complementary manner with variants of Afro-American 
religion like ocha and palo monte, comprising a religious continuum emically labeled « la religión » (Argyriadis, 1999a; Capone, 1999b : 51).

11. It may be argued that espiritismo, in its original, distinct form, is not strictly comparable with umbanda. However, when it is jointly practiced with santería (either as the separate but closely connected mode that Argyriadis (1999a, 1999b) describes for Cuba, or the mixed form that Brandon (1997) calls santerismo in the USA), it can be considered a "bridge » variant. In this sense espiritismo and umbanda are functionally equivalent in secondary religious diaspora settings. They are closer to preexistent belief systems and individuals generally start their socialization into trance experiences in these variants.

12. In several cases, however, the leader who passes from umbanda to candomble may stop the practice of the first variant (but see Epega, 1999: 166). Even then, umbanda has certainly served as a bridge to the practice of a more African variant.

13. The function of cognitive bridging may be more important than what it is thought also in primary diaspora settings -as is suggested by the fact that the joint practice of two or three variants seem to be the rule almost everywhere. However, because these religions are racialized, it is assumed that «black» individuals are born into them (Frigerio, 2002b). Probably because of this assumption, we have little data on the religious careers of individuals in primary diaspora settings. Argyriadis' revealing ethnography of «la religión » in Cuba (1999a, 1999b) shows that even in Havana individuals are more likely to start their religious career in espiritismo (1999a: 125). Lydia Cabrera pointed out several decades ago that «Spiritism has thousands upon thousands of adherents and thousands upon thousands of mediums » in Cuba (1975:30) and one of her informants stated: «el muerto en todas las reglas pare al santo» [the dead gives birth to the orisha] (1975: 62). My own experience in Salvador, Bahia shows that candomblé de caboclos -or giras de caboclos- is usually concurrent with candomblé ketu and individuals frequently start their religious careers working with caboclos and are only later initiated into candomblé. Corrêia (1992) and Oro (1994) ascertain that batuque in Porto Alegre is also mostly practiced jointly with umbanda. All these data suggest that, even in primary diasporas, these variants probably serve the same function of cognitive bridging.

14. The order in which the variants arrived in the USA depends on the group of migrants considered. In the case of Puerto Ricans, they brought espiritismo with them from their homeland and after some years in the USA, adopted santería. Brandon (1997) argues that within this community it is more adequate to talk of «santerismo " than santería proper, since they practice a mixture of both variants. Perez y Mena states that « Most Puerto Rican believers evolve from French Kardecian Spiritism toward incorporating aspects of Yorubaland religious practices " (1998: 22). According to the argument here developed, it makes sense that it is the Puerto Ricans (the population to which santería is more culturally alien) who most need to develop cognitive bridges between their more traditional practices (espiritismo) and AfroAmerican religions.

15. There are two variants that further complicate this scheme : kimbanda (for the expansion of Afro-Brazilian religions) and palo monte (for Afro-Cuban ones). Initiation into kimbanda, in the Southern Cone usually comes after the practice of umbanda and precedes initiation into batuque. During the 1990s, this variant has gained prevalence in the region -oftentimes at the cost of Umbanda. Argyriadis (1999a: 124-125) ascertains that in Havana initiation into palo monte similarly comes after the practice of espiritismo and usually precedes initiation into regla de ocha.

16. Africanization is a dynamic process, with further stages of its own. The passage from umbanda or espiritismo to candomblé, batuque or santería is generally only the first of a series of perhaps less dramatic but equally important initiations. Practically the same mechanics that drives umbanda leaders to become candomble pais de santo, leads them to undergo successive initiations into candomblé «nations» considered "purer». This process has been documented 
for São Paulo by Prandi $(1991,1998)$ and for Rio de Janeiro by Capone $(1996,1999 a)$. Both scholars stress that this passage generally enhances the reputation of the pai de santo, since it is always performed in the direction of a "purer ", more prestigious nation. Although I agree with this interpretation, I believe that successive initiations are not only a quest for prestige and legitimacy, but are also sought as a problem-solving strategy. Adding another dimension to their explanation, I contend that « purer » nations are emically prestigious not only because they are more legitimate but also because they are considered to be magically stronger.

17. Also, at an individual level, and contrary to re-Africanization, which is generally always a movement of independence, Africanization is a move towards increased dependence. After initiation, the individual becomes subordinated to his pai/mãe de santo or padrino/madrina and to all his related ritual elders. Brandon (1997 : 111) and Schmidt (1995: 100) ascertain that the bonds linking santería devotees (ahijada/o) with their initiators (madrinas/padrinos) is stronger than those present in espiritismo communities.

18. Even if an individual's padrino or pai de santo live in the same city, in all likelihood the ritual family of his mentor lives abroad -because these religions have only recently become transnational. Thus, almost any initiate in batuque, candomblé or santería knows that he has an important ritual family in another city, which he will visit periodically.

19. The community may be trinational (Argentinian-Brazilian-Uruguayan; Cuban-North American-Puerto Rican) but its members have a strong relationship only with the nationality of origin of their religion.

20. These are local, national religions that expand through the individual efforts of particular priests who enjoy having international disciples (Oro, 1999) but have made little efforts to denationalize or universalize their beliefs. Other local religions that have gone global, crossing ethnic and national boundaries, had a centralized organization, sent missionaries abroad with a clearer and more definite recruiting rationale and with greater amount of financial resources -as is the case of Japanese new religions, for instance.

21. See the revealing testimony of Sandra Medeiros Epega, an Africanized mãe de santo from São Paulo, herself a lecturer and author, to Silva (1995: 259) where she states that she must have made some 300 copies of a doctoral dissertation in Portuguese about the use of leaves in candomblé.

22. There are a few exceptions: the aforementioned yalorisha Sandra Medeiros became the spiritual daughter of a famous African babalawo, and adopted his name, becoming Sandra Medeiros Epega. Such cases, though, are rare.

23. It must be remembered that race barriers were already transcended with the expansion of these variants to the secondary diasporas. In cities like São Paulo, Montevideo, Buenos Aires and Mexico most of the practitioners are white, and in others like Rio de Janeiro or New York a very significant percentage of them are not Black.

24. We still lack a good study of this group and its strategies. Certainly the key figures involved are the Ooni of Ilé-Ifé, and two scholar-priests who held high positions in the Obafemi Owolowo University of the same city. The first is Oomotoso Eluyemi, a noted archaeologist and also the Apena of Ifé (the right hand of the King). The second is Wande Abimbola, who was head of the university and has published extensively on Ifa $(1976,1977)$. Nigerians who have taught Yoruba language and mythology in secondary religious diaspora settings are either related to this group or have later seeked their support -or to the very least, have heavily used their books. The Epegas, father and son, coming from a lineage of babalawos, must also be included in this group. The influence of this group in the spread of a re-Africanized interpretive frame can be likened to that of previous «Black ethnicity entrepreneurs » in the establishment and the extraordinary success of the "Yoruba traditional religion » in the New World (Matory, 1999).

25. The wording of the presentation for the VII World Congress of Orisa Tradition and Culture that was to take place in Nigeria, in 2001, is very representative of the global -not national- 
character assigned to the religion in this interpretive frame. It shows clearly how the Nigerian entrepreneurs who are one of the main driving force behind it are able to transcend local narratives with a global one. A statement that this is the third time that the conference will be held in Nigeria is the only oblique claim to this country's importance in the religious tradition. Early on the universal character of the tradition is emphasized as attention is called to the significant fact that « the Conference takes place at the Cradle of the Human Race, Ilé-Ifé » (their emphasis). The planetary relevance of the meeting is again immediately ratified by the remark that «Equally important is the fact that holding of this conference at the material time is apposite as the world is vigorously pursuing the ultimate aim of World Peace and Harmony. And since the time of Creation, Orisa Tradition has been the equilibrium that adjusts world forces! » (my emphasis). Twice in this short introduction the African -and not solely Nigerian- character of the event and of the religion are emphasized. First, by thanking all involved « in the making of the decision to hold the 2001 Congress in Africa and specifically in Ilé-Ifé », and then again, by explaining how the theme of the conference was determined «after spiritual validation and propitiatory rites by the priests, priestesses, and eminent scholars in the area of African Traditional Religion and Spirituality" (my emphasis). A final welcome "to the Source " (their emphasis) and the fact that the conference languages will be "Yoruba, English, Portuguese, Spanish and French" show, once more, the cosmopolitan character of the event. (The introduction can be found at http://www.geocities.com/orisaworldcongress/2001the-me.html)

26. See, for example, the opinions of Brazilian batuque leaders on their Argentine counterparts in Oro (1999).

27. For example, when the Ooni of Ifé visited a temple in Buenos Aires in 1991, he complimented its members telling them that they had kept the dances "just as they were done in Africa ", a remark which was quite visibly an overstatement, for dancing was not among the many virtues that the members of the temple could boast of.

28. However, the heavy racialization of Black culture still conspires against Afro-American religions attaining this status, in spite of their rapid expansion. African derived theological concepts and practices -especially animal sacrifices- are still, to a large extent, considered "primitive" and are not recognized as a legitimate spiritual quest in the Western world. Therefore, they are especially suspect when practiced by white people (Frigerio, 2002b). Judgments may be more condescending when they are practiced by Blacks, since then the ethnic cultural resistance functions of these religions take precedence over their alleged religious value. It is only when African religious beliefs and practices come to be recognized as a legitimate spiritual quest, one of the sacred legacies of mankind such as Buddhism or Hinduism, that they will be able to effectively achieve the status of a world religion.

\section{ABSTRACTS}

The most important recent development in the history of Afro-American religions is their expansion across ethnic and national barriers. The diffusion of these religions has created networks of ritual kinship that now span national boundaries giving rise to transnational communities of worshippers. The paper argues that there are stages in the formation of these transnational communities that are related to the religious careers of the practitioners, since the different religious variants they encounter in this path have different implications for their development. In this process of increasing transnationalization, the nationality of origin of the 
different Afro-American religious variants remains important and must be dealt with in different ways throughout the individual's religious career. It is argued that the re-Africanization processes that have been observed in practically all Afro-American variants in their new settings constitute the latest stage in the development of these religions and that they are instrumental in the creation of a world religion and of a truly multifarious transnational community of worshippers.

La principale évolution récente des religions afro-américaines est leur expansion par delà les barrières ethniques et nationales. La diffusion de ces religions a créé des réseaux de parenté rituelle qui maintenant dépassent les frontières nationales donnant naissance à des communautés transnationales de fidèles. Cet article met en évidence le fait qu'il y a des étapes dans la formation de ces communautés transnationales qui sont liées à la «carrière " religieuse des pratiquants. Les modalités des pratiques religieuses suivies par leur membres influencent le développement de la communauté. Dans ce processus de transnationalisation croissante, la nationalité d'origine des différentes religions afro-américaines reste importante et doit être prise en compte dans les differents mode d'évolution religieuse individuelle. Le processus de réafricanisation s'observe dans pratiquement toutes les variantes des cultes afro-américain, où qu'ils soient implantés : il constitue la dernière étape de développement de ces religions et contribue à la création d'une religion universelle et d'une communauté de fidèles transnationale et multiforme.

\section{INDEX}

Mots-clés: religions afro-américaines, diaspora, transnationalisation, réafricanisation

Keywords: Afro-American religions, diaspora, transnationalization, re-Africanization

\section{AUTHOR}

\section{ALEJANDRO FRIGERIO}

Alejandro Frigerio est chercheur du CONICET (Conseil national pour la recherche scientifique et technologique) et professeur de l'Université Catholique Argentine. Il est l'auteur de plusieurs ouvrages, parmi lesquels Cultura Negra en el Cono Sur : Representaciones en conflicto (Ed. de la Universidad Católica Argentina, 2000) et Argentinos e Brasileiros : Encontros Imagens e Estereótipos (Ed. Vozes, 2002, avec Gustavo Lins Ribeiro). Il poursuit actuellement ses recherches sur la transnationalisation des religions afro-brésiliennes en Argentine. 